International Journal of Linguistics, Literature and Translation

ISSN: 2617-0299 (Online); ISSN: 2708-0099 (Print)

DOI: 10.32996/ijltt

Journal Homepage: www.al-kindipublisher.com/index.php/ijltt

IJLLT

\title{
Audience Demands as a Strategic Maneuver in Imam Al-Hassan's Speech after his Truce with Muaawiya
}

\author{
Prof. Fareed Hameed Al-Hindawi ${ }^{1}$ (D) and Basim Jubair Kadhim ${ }^{2}$ (D) $\triangle$ \\ ${ }^{7}$ Head of the Department of English, Islamic University, College of Education, Al-Najaf, Iraq. \\ 2Lecturer, Ministry of Education Al-Najaf Education Directorate, Najaf, Iraq \\ $\triangle$ Corresponding Author: Basim Jubair Kadhim, E-mail: basimjuabir1984@gmail.com
}

ARTICLE INFORMATION
Received: April 11, 2021
Accepted: May 24, 2021
Volume: 4
Issue: 5
DOI: $10.32996 /$ ijllt.2021.4.5.27

\section{KEYWORDS}

Pragmatics, Audience Demands, Imam Al-Hassan, Argumentation

\section{ABSTRACT}

Strategic maneuvering is an extended version of pragma-dialectics. It manifests itself in three basic aspects, p. topical potential, audience demands, and presentational devices. These aspects are interrelatedly used with each other. The aspect of audience demands, which is the concern of this study, indicates the use of cultural, conventional and common-sense knowledge of the audience's preferences, following particular presentational devices as strategies. Thus, in their attempts to reasonably and effectively persuade the audience, speakers resort to this strategy in their endeavor to win the audience support. The use of this strategic manoeuvre in this concern seems to have not received its due scholarly attention from a pragmatic angle, particularly in religious discourse. Hence, this study attempts to bridge this gap in the literature via scrutinizing the speech of Prophet Muhammad's (PBUH) grandson, Imam Al-Hassan son of Ali Bin Abi Talib (PBUT). This speech is considered as one of the most notable speeches in the Shiite theology. Imam Al-Hassan (PBUH), as the caliphate of Muslims, delivered this speech after the truce which was held between him and Muaawiya, the leader of the Umayyad people. To unravel the pragmatic features of strategic maneuvering in this speech, the current work addresses fulfilling audience demands by using certain presentational devices in this speech. In so doing, the study attempts to find out the persuading manifestations and rhetorical effects that influence the audience and change their attitude. To achieve those aims, the study appeals to Emeren and Houtlosser's (2002) model for the pragmatic analysis of the speech in question. This analysis yields certain findings among which is Imam AlHassan's (PBUH) exploitation of specific cultural issues related to Muslims as pragmatic strategic maneuvers that fulfill their demands.

\section{Introduction}

Strategic maneuvering is development to dialectics which is defined as the art of reasonably persuading others using arguments and argumentation through the utilization of critical discussions. Emeren (2001,p.12) introduces strategic manoeuvrings as the rhetorical aspect used to affect the audience and convince them. In this perspective, certain linguistic phenomena are pragmatically employed by speakers who have an influence on addressees, following special available linguistic strategies (Houtlosser, 2001, p. 30-3). The main basic aspects: topical potential, audience demands, and presentational devices. These aspects are interrelatedly used with each other (Emeren \& Houtlosser 2002, p. 16). The aspect of audience demands, which is the concern of this study, indicates the use of cultural, conventional and common-sense knowledge of the audience's preferences, following particular presentational devices as strategies.

Thus, in their attempts to reasonably and effectively persuade the audience, speakers resort to this strategy in their endeavor to win the audience support. The use of this strategic maneuver in this concern seems to have not received its due scholarly

\section{K C AL-KINDI CENTER \\ $\mathbf{R}$ D FOR RESEARCH AND DEVELOPMENT}

Your gateway to world-class research

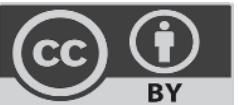

Published by Al-Kindi Center for Research and Development, London, United Kingdom. Copyright (c) the author(s). This open access article is distributed under a Creative Commons Attribution (CC-BY) 4.0 license 
attention from a pragmatic angle, particularly in religious discourse. Hence, this study attempts to bridge this gap in the literature via scrutinizing the speech of Prophet Muhammad's (PBUH) grandson, Imam Al-Hassan Bin Ali Bin Abi Talib (PBUT). This speech is considered as one of the most notable speeches in the Shiite theology. Imam Al-Hassan (PBUH), as the caliphate of Muslims at that time, delivered this speech after the truce which was held between him and Muaawiya, the leader of the Umayyad people.

To unravel the pragmatic features of strategic maneuvering in this speech, the current work addresses fulfilling audience demands by using certain presentational devices in this speech. In so doing, the study attempts to find out the persuading manifestations and rhetorical effects that influence the audience and change their attitude. To achieve those aims, the study appeals to Emeren and Houtlosser's (2002) model for the pragmatic analysis of the speech in question.

\section{Strategic Maneuvering}

Bridging the gap of dealing with the reasonableness of dialectics, Emeren and Houtlosser (2002, p. 1-13) introduce a relatively new account of pragmatic concepts along with rhetorical manifestations. This development is found to serve communication breakdowns in the critical discussion and violations of the rules of the critical discussions (ibid, p. 135). Such pragma-rhetorical aspects are strategic maneuvers whose pragmatic functions are to manage the argumentation strategies in the four strategies of the critical discussion. The critical discussion is what the protagonist (one party) and antagonist (the other party) are involved in to either defend or reject a standpoint (Emeren \& Grootendorst, 2004, p. 32). Such a critical discussion contains four stages, p. opening stage, confrontation stage, the argumentation stage and the concluding stage. Each of these four stages contains certain linguistic strategies (presentational devices) that are pragmatically chosen to be used to move for the strong arguments (Andone \& Gaja, 2011, p. 13).

Emeren (2010, p. 93) presents a triangular, interrelated three aspects of using strategic maneuvering to rhetorically persuasive devices. These are as follows:

a. Topical potential refers to the selection of certain topics from a set of available topics to defend a standpoint. These topics are used in different contextual commitments to be variously effective (Emeren \& Grootendorst, 1992, p. 143).

b. Audience demand indicates that arguers resort to what pleases the audience, i.e., selecting topics that are achieved through certain linguistic realizations that are culturally, conventionally and logically suitable for the audience (ibid, p. 94).

Accordingly, to be more effective and persuasive, arguers adapt the most optimally accepted preferences to agree with what the audience wants (Emeren, 2015, p. 14).

Certain principles are considered as accepted by the audience. The acceptance is based on the optimally measured conventions that are agreed upon. Such adaptation should be made along all the four stages of critical discussion to create the required communion by depending on specific contextual commitments.

A. confrontation stage, p. avoiding the contradictions between the parties that appear unsolvable.

B. Opening Stage, p. conferring widely shared value judgement on personal feelings and impressions...

C. Argument stage, p. quoting arguments of other parties to lead the audience who agree with what's quoted to agree with or adhere to the speaker.

Certain comments are introduced regarding Emeren and Houtlosser (2002) workability in terms of "party's views and preferences". Fairclough (2009, p. 135) criticizes the view of adaptation, believing that all the beliefs and values should be taken into account.

More specifically, Tindale (2009, p. 43) attains that context is the core element in audience demand, justifying the preferences to the adaptation of all the stages of the audience demand is a stage-specific context sensitive aspect. This leads Rees and Rigotti (2011, p. 208) to review the adaptation of audience demands under the account of common ground between the addresser and the addressee.

According to O'Keefe (2009, p. 285), a relevant audience is asserted, following Emeren et al. (2002, p. 8-10) classification of the audience (two types of audience, p. primary and secondary). They (ibid) adopt the primary audience as the audience for whom the contextual commitments and pragma-rhetorical strategies are used.

This indicates that audience demand as broad strategic maneuvering should be context-dependent as well as relevant in a way that the addresser directs all the speech acts towards them. 
C. Presentational Devices refer to the linguistic realizations that are utilized to preset the standpoints in the critical discussion. In other words, such devices are the speech acts - in all the types and pragmatic implications- of the strategic maneuvering (Zarefsky, 2006, p. 400-1). Parts of such presentational devices are those devices used in audience demands, i.e. the speech acts used by the arguers to seek the audience's preferences to be more effective and persuasive (Emeren, 2010, p. 93).

Based on the Gricean maxims of the cooperative principle and politeness strategies, arguers adopt specific figures of speech as presentational rhetoric devices to appeal to the audience demands (ibid). These figures of speech or tropes are regarded as argumentative strategies to manoeuvre in terms of convergence.

Maneuvering is said to be either vertical or horizontal convergence. Vertical convergence refers to the utilization of manoeuvring aspects to reinforce each other vertically. On the other hand, horizontal convergence refers to the consecutive effect of the aspects, respectively.

\section{Imam Al-Hassan (PBUH)}

Al-Hassan (PBUH), who is nicknamed as Al-Mujtaba, is the eldest son of Imam Ali and the second caliphate in Shiite doctrine. His mother is Lady Fatima, the daughter of the Prophet (PBUH\&HF) who greatly loved Imam Al-Hassan (PBUH) during the seven years with the prophet before the latter's death (Al-Qarashi, 2011, p. 9-10).

Imam Al-Hassan (PBUH) took the Muslim leadership night after the martyrdom of his father Imam Ali (PBUH), where thousands of Muslims elected him. However, Muaawiya refused - an opponent leader in Syria- sent an army to confront Imam Al-Hassan (PBUH), setting different rumours among Muslims in Kufa as preparation for truce.

Imam Al-Hassan (PBUH) had been subjected to assassination; attempts that led him to be wounded. While he was being treated, certain people in Kufa who are proponents of Muaawiya kept sending letters to the latter telling him to deliver or kill Imam AlHassan (PBUH). After Imam Al-Hassan (PBUH) discovered this treason, he suggested making a truce with Muaawiya leading Muslims according to the holy Quran and prophetic tradition, with certain conditions. This truce had caused some followers of Imam Ali and Al-Hassan who regret the idea of truce, claiming that Imam Al-Hassan (PBUH) humiliated the Shiite followers (ibid, p. 479-82).

Imam Al-Hassan (PBUH) remained the only true, legitimate religious authority for all Muslims in spite of all the brutal practices used against the Shiite followers. His life ended under one of his wives, whom Muaawiya hired to poison the Imam. This came as a way to put Yazid - Muaawiya's son - on the throne (Al-Ameen, 1976, 577).

\section{Data Description \& Analysis}

\subsection{Data}

In order to set a model to be followed in the analysis of the speech selected, this section is allotted to the data selected for analysis, the introduction of the model of analysis, and the analysis.

Regarding the data, one of the most eminent speeches in the Shiite theology has been selected, namely, the speech of Imam AlHassan (PBUH) after the truce with Muaawiya. This is recognized by many conflicting opinions and criticisms that make it interpreted, studied and commented on by many accounts of different scholars in religious theology. Some argue that this speech is a kind of surrender to Muaawiya; others think it is not. Analyzing the linguistic devices in this speech in terms of pragmatic maneuverings can reveal certain linguistic interpretations to demystify all negative criticisms.

\subsection{Method of Analysis}

\subsubsection{The Model}

Since the model of strategic maneuvering as stipulated by Emeren and Houtlosser (2002) is extended on the four stages of the critical discussion, the speech under analysis is recognized by its argumentation stage. Hence, it is wise to focus on the strategies used in this stage, which necessitates the adaptation of the aforementioned model. Concerning the three aspects of maneuverings, only audience demand is selected to be the broad strategy employed by Imam Al-Hassan (PBUH) and the presentational devices are the sub-strategies of the audience demand, as in figure one: 


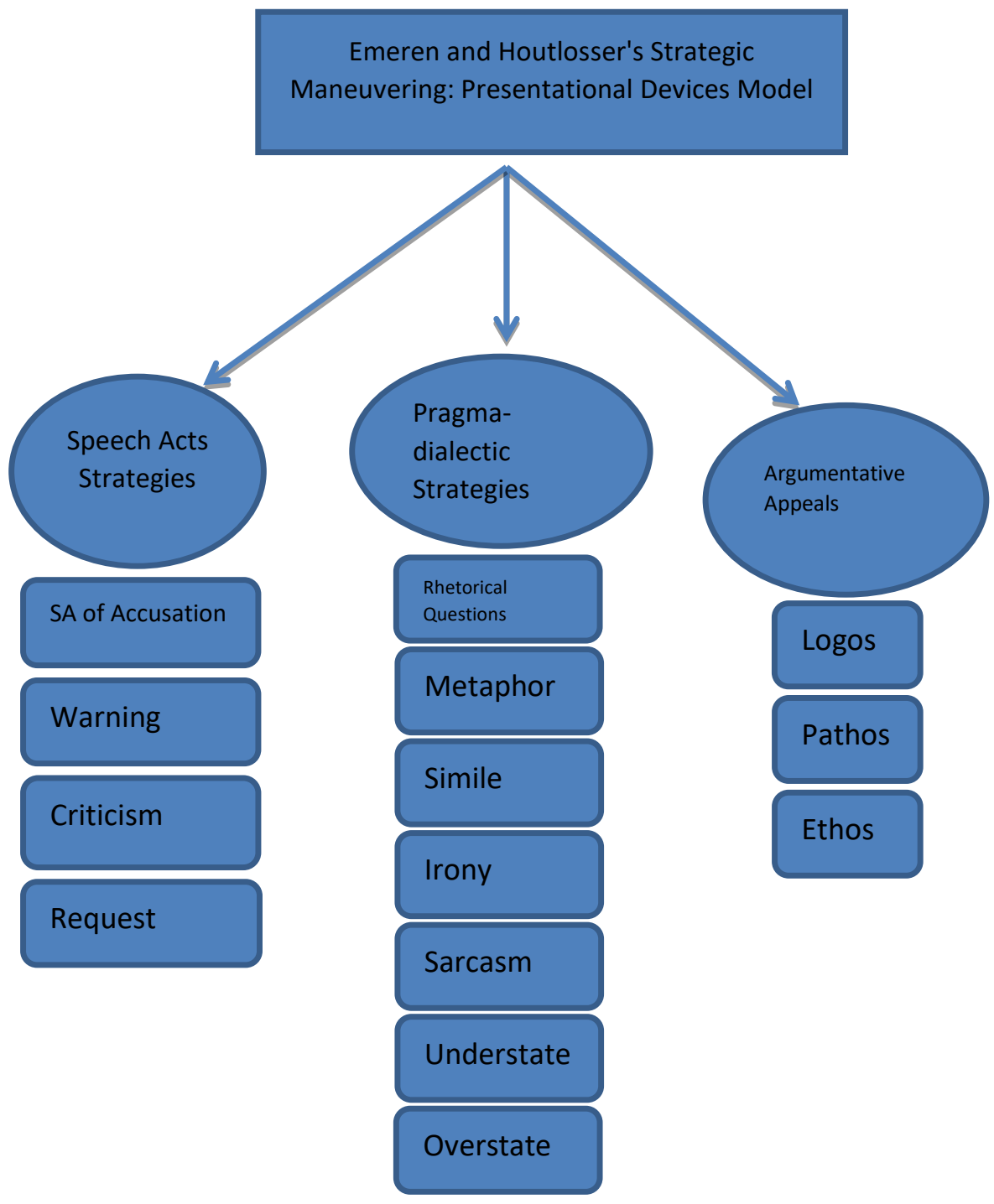

Figure 1: Eemeren and Houtlosser's Strategic Maneuvering (2002): Presentational Devices Model

Three main strategies represent the strategies of the presentational devices. Speakers may resort to certain speech acts such as accusations, warnings, criticism, and requests. These speech acts are the most frequently utilized in maneuvering. The second type is the utilization of pragma-dialectic strategies. These strategies are referred to as the tropes as rhetorical questions, metaphor, simile, irony, sarcasm, understatement (litotes), and overstatement (hyperbole). As for the third type, speakers may use argumentative appeals as stipulated by Emeren (2010, p. 109); logos, pathos and ethos.

Dealing with speech acts as introduced by Austin (1962) and elaborated on by Searle (1969), Emeren and Grootendorst (1984, p. 18) argue that particular speech acts can be used centrally as elements in the analysis of communicative acts, within which speeches are included. In strategic maneuvering, they (ibid) mention four speech acts as briefed below.

\subsubsection{Speech Act of Accusation}

Issuing accusation threatens the addressee's face; meaning that the illocutionary force is to reject a standpoint through the type of speech acts that attack the person's face -threatening speech act. (Andone, 2010, p. 135). Thus, it can be utilized as a pragmalinguistic strategy to neglect one's right to have a standpoint.

\subsubsection{Speech Act of Warning}

Warning involves "the giving of a decision in favor of or against a certain course of action. Or advocacy of it [...]. Its consequences may be that others are 'compelled' or 'allowed' or 'not allowed' to do certain acts" (Searle, 1977, p. 35). In terms of compliance and permission, such a kind of speech act can be employed in maneuvering in the sense that the addressor seeks what is good for the addressee through advising for instance (Lyons, 1977, p. 746). According to Quirk et al. (1985, p. 177), to issue a speech act through certain other linguistics realizations is to warn someone in favor or against action. 


\subsubsection{Speech Act of criticism}

Following Tracy et al. (1987, p. 56), to criticize is to find what is fault in one's utterances and attitudes, leading to illocutionary force which is of negative evaluation. Nguyen $(2005$, p. 7) further defines criticizing as "an illocutionary act whose illocutionary point is to give a negative evaluation of the hearer's $(H)$ actions, choice, words, and products for which he or she may be held responsible". Such kind of speech act can be used for the purpose of maneuvering and defeating a standpoint (Emeren $\&$ Grootendorst, 1984, p. 138)

\subsubsection{Speech Act of Request}

One of the most frequent speech acts that are used politely is the speech act of request; widely examined pragmatics. The speech act of request has a certain illocutionary force which represents seeking the hearer's ability to do something (Sifianou, 1999, p. 158). Searle (1969, p.71) defines requesting as "an attempt to get a hearer to do something". This attempt to get a hearer to do something is referred to as the perlocutionary effect of the illocutionary act of requesting. In terms of SM, Emeren and Grootendorst (1984) formulate the essential condition of the speech act of argumentation by linking it with an attempt to achieve the perlocutionary effect of convincing. They state that "in the case of all illocutionary acts, including assertives, the intended perlocutionary effects are the core elements in the formulation of the essential condition" (Andone, 2009, p. 167). Thus, requesting means that the antagonist requests the protagonist to perform argumentation

\subsubsection{Pragma-rhetorical Strategies}

The second sub-strategies in the model of this study are employing certain rhetorical devices for pragmatic purposes. They are rhetorical question, irony, metaphor, simile, understatement, overstatement, argumentative appeals. All these can be used as strategies for maneuvering to persuade the addressee rhetorically.

\subsubsection{Rhetorical Question}

Rhetorical questions are widely investigated and defined as they are hugely used in many pragmatic domains for their power of presupposition (Larson, 1984, p. 474). A rhetorical question can be simply defined as the question whose illocutionary force is not interrogative, it is rather emphatic. This means that such a question is to emphasize a certain idea Henkemans (2009, p. 15).

Taraman (2010, p. 4) details the importance of rhetorical questions through presenting the three defining properties as: they "can be followed by responses of agreement or disagreement", they "can function as valid answers to genuine questions" and they are "functioning as answers can often be interpreted as argumentative".

\subsubsection{Metaphor}

Metaphor is one of the most important use figures of speech as it is flexible and creative in bringing new meanings through the use of conventional linguistic forms (Cruse, 2006, p. 106). Carver and Pikalo (2008, p. 221) introduce two types of metaphor, p. novel metaphor and conventional metaphor. These two types are discussed under the conceptual theory of metaphor (Lackoff \& Johnson, 2000). The novel metaphor refers to the newly encoded and represented in the mental lexicon, while conventional metaphor refers to the already encoded meaning in the mental lexicon (ibid).

As far as strategic maneuvering is concerned, Emeren and Houtlosser (2002, p. 41) assert that the use of metaphor for its creativity and flexibility to maneuver the utterances pragmatically as well as rhetorically.

\subsubsection{Simile}

Simile is one reflection of metaphor with the apparent use of comparative particles, making the comparison as direct as it is understood. This can also be utilized in strategic maneuvering as a rhetorical device (ibid).

\subsubsection{Irony}

The irony is another important figure of speech that is essentially utilized in strategic maneuvering. Speakers use certain utterances that are not genuine at the level of intentionality (Roy, 2008, p.407). In other words, there is a discrepancy between the speaker's utterances and intentions. This is pragmatically used and can best serve as a strategy to maneuver. It is based on the cooperative principle and politeness principle, following Brown and Levinson (1987, p.221).

\subsubsection{Sarcasm}

Colston and Gibbs (2007, p. 23) present sarcasm as a strategy of issuing ironic utterances to convey verbal irony through the property of discrepancy. However, its intention is negatively oriented, in the sense that the surface utterance to praise, for instance, but the intention is to criticize. Dews and Winner (2011, p. 1574) attain that sarcasm is used in pragmatics to serve as a face-saving act toward the speaker. Here is the role of maneuvering manifested in the sense that the speaker maneuvers by using polite utterances to convey the opposite intention (ibid). 


\subsubsection{Overstatement}

Overstatement, or hyperbole, is the magnification of reality through generating implicatures when violating the CP maxims, i.e. saying more than required (Holtgraws, 2002, p. 144). It is already used as hyperbole - figure of speech- when the exaggeration is rhetorically manifested (Leech, 1983, p. 143).

\subsubsection{Understatement}

Understatement is the opposite of overstatement in that using utterances to convey the idea in a less significant than reality, for pragmatic purposes such as ironic or sarcastic (Sperber \& Wilson, 1992, p. 53-76). Israel (2002, p. 1) asserts the rhetorical use of the term of litotes when rhetorically violating the CP maxims to generate certain implicatures that could lead to downgrading the situation for pragmatic purposes. This can be used as a strategy to maneuver in speeches, as demonstrated by Emeren and Houtlosser (2002, p. 39).

\subsubsection{Argumentative Appeals}

According to Emeren and Grootendorst $(1992$, p. 89) maneuvering can be achieved by utilising argumentative appeals. They are briefed below.

\subsubsection{Logos}

This appeal is employed with critical cognition, analytical skills, purposeful conduct and factual statements. These can be used in carrying out the argumentation when speakers are in positions where they feel more persuasive when adopting logos (Gottweis, 2007, p. 241).

\subsubsection{Pathos}

Pathos is concerned with the audience in the sense that how the audience can be motivated and moved by strong effect of the speaker's utterance. This can be pragmatically utilized in maneuvering (Kemp, 2001, p. 5).

\subsubsection{Ethos}

Ethos deals with the speaker's credibility or ability to persuade and affect others, following Boone and Kurtz (1999, p. 41) certain properties are introduced regarding the speaker's credibility such as having ethical qualities, trustworthiness and sincerity.

All the above-classified strategies can be used as presentational devices to affect and rhetorically convince the audience through certain contextual commitments.

\subsection{Analysis}

Only the utterances that contain the strategic maneuverings are mentioned, translated and analyzed here.

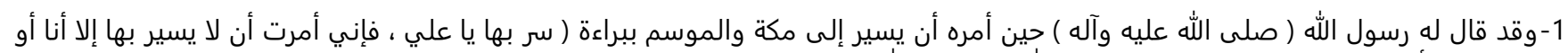

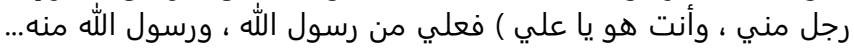

1. The messenger of Allah, when he ordered imam Ali to go to Makka and Almawsim, says, p. "Ali, you do lead because I order that no one lead but me or one just like me who is you, Ali". Thus, Ali is the same as the messenger of Allah....

The speaker (Imam AL-Hassan(PBUH)) enumerates certain facts that the audience (Muaawiya and the audience) are well aware of his relation to the prophet and Imam Ali, using logos to try to implicate to the audience that he is the legitimate one for the caliphate. Again, the quantity maxim is violated by giving more information than required under the use of overstatement ( إلا (أنا أو رجل مني ، وأنت هو يا علي presupposes that the audience have positive attitude toward his mention.

$$
\begin{aligned}
& \text { 2- وإنه أقرب المقربين من الله ورسوله ، وقد قال الله ( عز وجل ) .p , ( والسابقون السابقون * أولئك المقربون ) وكان أبي سابق السابقين إلى الله }
\end{aligned}
$$



2- He is the closest to Allah and the messenger. Allah says "the earlier in Islam is the closer". My father [Imam Ali] was the earliest to Allah and to his Messenger (PBUH\&HF).

In this excerpt, the Imam uses a Quranic verse in its metaphoric sense ( والسابقون السابقون * أولئك المقربون a kind of intertextuality to express the role of his father Imam Ali and the commitment to the prophet. The Quranic verse is known to the addressees (Muaawiya and the audience). Thus, the Imam tries to use this metaphor as a textual implicature that flouts the quality maxim throughout the verse to refute Muaawiya's standpoint through the presupposition of commitment to Islam. Here, the Imam (PBUH) employs the presupposition (pragmatic presupposition) to maneuver that all the addressees know the occasion of the above mentioned verse revelation. 
3- وذلك أنه لم يسبقه إلى الايمان أحد ، وقد قال الله ( تعالى ) . , ( والسابقون الأولون من المهاجر ين والأنصار والذين اتبعوهم بإحسان ) فهو

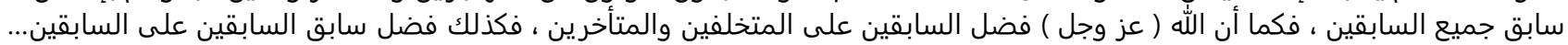

3. No one is before him in faith, as Allah says "the earlier the first whether migrants and supporters and those who follow them in good". Thus, he is the earliest. Since Allah honors the earlier to the late, Allah honors the earliest...

The speaker uses the Quranic verse to refer to the legitimacy of Imam Ali's (PBUH) role in Islam. The Quranic verse is used as an intertextual device to maneuver through the presupposition that the addressees are aware of the interpretations of the holy verses. Through the interpretations, the Imam utilizes them to generate a textual implicature in a polite way to refer to the addressees that Muaawiya's argument should be rejected for the reasons that are implicated in the interpretations of the holy verse. Since the addressees know the implications of the verses, they can easily be convinced of the addressor's standpoint. This is used as strategic maneuvering to achieve the addressor's standpoint.

$$
\text { 4- وجعل الله عليه وآله ) من مسجد رسول الله بألف صلاة في سائر المساجد إلا مسجد خليله إبراهيم ( عليه السلام ) بمكة ، وذلك لمكان رسول الله ( }
$$

4. Allah makes the prayer in the Messenger's mosque reward as if thousands of prayers are offered in other mosques except the most of Allah's beloved the prophet Ibraheem due to the status of the messenger of Allah...

Here, the simile is utilized to generate implicature using the highest politeness strategy of rhetorical means to show the prophet's holiness through narrating factual, historical accounts. The implicature here is to demonstrate the reason (logos) appeal to convince the addressees to reject protagonist standpoint and accept the Imam's (PBUH) (antagonist) standpoint.

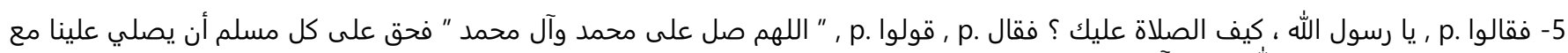
الصلاة على النبي ( صلى الله عليه وآله ) فريضة واجيك فقالة...

5. They said, p. "how should we pray on you?" he [the Messenger] said, p. "it is to say peace be upon Muhammad and his family". This is a duty on each Muslim who prays on us when praying on the prophet...

Here, the Imam (PBUH) employs the speech act of request to remind the addressees of what the prophet and asked people to do in terms of praying on Muhammad and his family. Using the speech act of request is to defend the Imam's standpoint which is agreed upon by both the addressor and the audience. The speech act of request is strategically used to maneuver and generate an implicature via flouting the maxim of manner; i.e., to implicate speech act to direct the audience to comply with the addressor's argument.

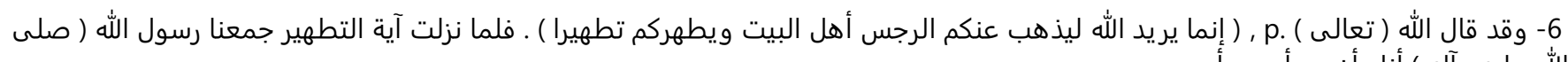

$$
\begin{aligned}
& \text { الله عليه وآله ) أنا وأخي وأمي وأبي.... }
\end{aligned}
$$

6. Allah says, p. "Allah wants to remove the impurity from you Ahlulbait and to completely purify you. Such verse was revealed in our favor, p. my father, mother, brother and I...

The Imam (PBUH) uses another Quranic verse which indicates a strategic maneuver through the intertextual device and seeking what is common between the audience and him. He employs this verse to generate an implicature through the most characteristically polite manner. Here, the Imam uses this verse to indicate to the addresses that they should be convinced with his standpoint as it is commonly known to both the addressor and the addressees. Consequently, the Imam relies on the presupposition which is related to the holy verse as a maneuver to prove his argument.

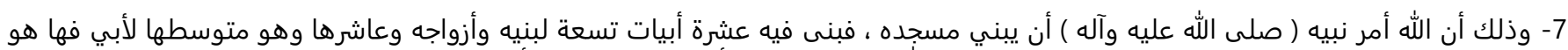

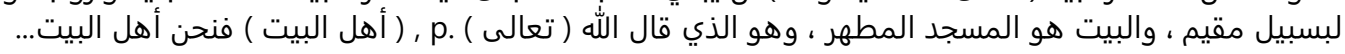

7....that Allah ordered the Messenger (PBUH\&HF) to build his mosque, and the messenger did build ten houses: nine of them to his family and wives and the tenth is for my father in a straight path. The house here is the pure mosque, the name which the exalted Allah uses for us: Ahlulbait...

The Imam (PBUH) uses one of the argumentative appeals: pathos, to address a common issue that the addressor and the addressees are well aware of. This pathos is to refute Muaawiya's standpoint. Pragmatically speaking, pathos is conveyed through issuing such speech acts as an assertion to convey metaphoric sense through the comparison between the purified mosque and the family of the Messenger. Violating the quantity maxim is applied to generate implicature to strengthen the speaker's argument and lead the audience to accept the addressor's standpoint. 


$$
\text { 8- وإن معاوية بن صخر زلعم أني رأيته للخلافة أهلا ، ولم أله أر نفسي لها أهلا ، فكذب معاوية ، وأيم الله لأنا أولى الناس بالناس في كتاب الله وعلى }
$$

8. Muaawiya claimed that I found him qualified enough for the caliphate, and did not find myself qualified enough. Muaawiya lies. I swear by Allah that I am the best suitable and legitimate caliph, if we follow Quran and the Messenger's tradition...

Imam Al-Hassan (PBUH) employs understatement through using the name "Muaawiya" without any title. The Imam also uses speech act of criticism through exposing Muaawiya's lies, seeking the audience's approval to reject Muaawiya's standpoint of argumentation. Using these two strategies, the antagonist tries to generate implicature to the addressees and seek their knowledge regarding the protagonist's standpoint. The aim is to legalize the rejection of the aforementioned standpoint, using the on record politeness strategy by addressing the addressee directly.

$$
\text { 9- غير أنا لم نزل أهل البيت مخيفين مظلومين مضطهدين منذ قبض رسول الله ( صلى الله عليه وآله ) ، فالله بيننا وبين من ظلمنا حقنا... }
$$

9. However, we are still Ahlulbait, intimidating, oppressed and prosecuted since the time of the Messenger of Allah (PBUH\&HF). Allah is the one who will do justice to those who oppressed us and who took our rights...

The Imam (PBUH) here uses the speech act of warning pragmatically, issuing it to the addressees and at the same time generating implicature to refute Muaawiya's standpoint through the warning. Such speech act is issued through employing mediator strategy (powerful entity, p. Allah). This mediator is common and is an arbitrator between the addressor and the addressees, an entity that both the protagonist and antagonist should fear. Using this strategy and speech act by Imam Hassan implies that since the audience knows the mediator, they will be warned and stopped believing the protagonist.

$$
\text { 10- وقد رأوا رسول الله ( صلى الله عليه وآله ) حين نصبه لهم بغدير خم وسمعوه ، ونادى له بالولاية ، ثم أمرهم أن يبلغ الشاهد منهم الغائب... }
$$

10... they have seen the Messenger (PBUH\&HF) when instating him [Imam Ali] at GhareerKhum, hearing the messenger call the caliphate of Imam Ali, ordering then to tell all those who are not present...

The Imam (PBUH) uses the speech act of accusation by giving evidence directly from the Messenger and accordingly, he accuses the addressee not to follow the Messenger's order. This is a strategy to maneuver to reject Muwawiayah's argument. The speech act of accusation is issued by using the indirect strategy to generate the implicature in a polite way. This causes the protagonist's standpoint to be rejected by the audience as the audience is well aware of Ghadeer Khum's event. The antagonist presupposes that they know such an event and employs it to maneuver the win the argumentation.

$$
\text { 11-وقد خذلتني الأمة وبايعتك يا بن حرب ، ولو وجدت عليك أعوانا يخلصون ما... }
$$

11. People let me down, ibina Harb, so I pledged homage to you. If have found supporters, I would have not pledge homage for you.

The Imam uses understatement to refute Muawiaha's argument. This understatement (يا بن حرب) is pragmatically used where implicature is conveyed through the violation of manner maxim for the purpose of maneuvering to reject Muaawiya's standpoint. At the same time, the addressees know that it is common for one to call Muaawiya ibn Harb when underestimating his status. The antagonist using pathos as a justifying strategy for his choice. The pathos is that the audience realized the Imam would never pledge homage to Muaawiya if the people are by his side.

$$
\text { 12- فاتقوا الله ولا تضلوا بعد البيان ، وكيف بكم وأنى ذلك منكم ! ألا وإني قد بايعت هذا - وأشار بيده إلى معاوية... }
$$

12. Thus, fear Allah, do not be misguided after the utter guidance. How do you believe that I pledged homage to this indicating to Muaawiya...

Three strategies are used, p. speech act of warning, rhetorical question, and understatement. Using speech act of warning indirectly is to reject the protagonist's standpoint. Using warning means that the argument is not right to be followed. The use of rhetorical question is to seek the audience demand, without the protagonist as an astonishing strategy that they believe and follow the protagonist. Furthermore, understatement through indicating to Muaawiya is another refuting strategy, where the antagonist is not convinced by the protagonist and neither by the protagonist's standpoint. All these three strategies are used to maneuver to reject the argument.

$$
\begin{aligned}
& \text { 13- أيها الناس ، اسمعوا وعوا ، واتقوا الله وراجعوا ، وهيهات منكم الرجعة إلى الحق ، وقد صارعكم النكوص ، وخامركم الطغيان والجحود ( } \\
& \text { أنلزمكموها وأنتم لها كارهون ) والسما واتلام على من اتبع الهدى وهئ... }
\end{aligned}
$$

13. O people, listen, be aware, fear Allah, and hold yourselves accountable... 
The Imam (PBUH) uses speech act of ordering (direct order) to advise and ask people to go back to the right path, indicating that they are supposed to follow the prophetic tradition. Using direct politeness strategies is through the social variable in terms of politeness strategy. Power is the most important one. Thus, the antagonist uses the direct order as a manoeuvring strategy to reject the protagonist's standpoint due to the powerful position that the protagonist has. The addressees are remained by the antagonist's utterances in order to be used as another rejecting strategy to the protagonist's argument.

\section{Discussion}

The antagonist (Imam Al-Hassan (PBUH)) uses such pragmatic principles as a cooperative principle (violating it to generate implicature), and politeness principle to be strategically maneuvering and presupposition for the purpose of audience demand.

Starting with the strategies used by Imam Al-Hassan (PBUH), the three types outlined in the model are employed under different sub-strategies from each type, following Emeren and Houtlosser (2002). Other strategies which are not mentioned in the model are used. As far as the speech acts which are used as strategic maneuvering strategies are concerned, the following are used, $p$. speech act of request is used in utterance 6 , criticism is used in 8, the warning is used in 9 and 11 and accusation is used in 10. Other speech acts that are not included in the model are speech acts of order in 5,10 , and 13, and assertion in 7 . Such use indicates the higher status of Imam Al-Hassan (PBUH), based on Zarefsky (2006, p. 400-1), to have a considerable understanding of the contextual commitments in the sense that these speech acts require power to be issued. Imam Al-Hassan (PBUH) can refute the protagonist's standpoint through using his powerful status and issue such speech acts.

Imam Al-Hassan (PBUH) employs rhetorical devices with pragmatic manifestations at a large scale (following the style of Imam Hassan and Ahlulbait). He employs metaphor in utterance 1, simile in 4, understatement in 8,11, and 12, and rhetorical questions in 12. The utilization of such pragma-rhetorical strategies is devoted to showing the position of the protagonist and the true attitude of the antagonist through seeking the audience acceptance that the antagonist's (Imam Al-Hassan (PBUH)) standpoints are accepted as the addressees are well acquainted with all the antagonist's arguments (see Emeren \& Houtlosser, 2006, p. 381). Other pragma-rhetorical devices are employed here such as intertextuality in 2,3,and 6 (mentioning relevant Quranic verses) and divine powerful names in 9 (using Allah's name) are used to remind the addressees of the things that are common to all; i.e. appealing to audience demand as O'Keefe (2009, p. 285) mentions.

Concerning the use of argumentative appeal, Imam Al-Hassan (PBUH) uses logos in the utterances 1 and 2 in which he mentions certain logical arguments such as his lineage and relation to the prophet and Imam Ali. This is used when the speaker is not in a position of beseeching someone or seeking Muslims' emotions to be convinced. The other argumentative appeal is that using pathos in utterance 8 where Imam Al-Hassan (PBUH) brings the Islamic issue that addressees have in common, telling them that he is the legitimate one to be the leader of the Islamic nation.

The speech which has been analyzed under Emerenand and Houtlosser's 2002 model, is workable to a certain extent in that most of its strategies are manifested leaving few ones such as irony. All the strategies that have been demonstrated in the speech are regarded as presentational devices to seek the audience demand for the purpose of convincing the addressees. In other words, the interrelation between the three aspects of strategic maneuvering can be used as strategies that complete each other, as attained by Henkemans (2009, p. 17-9). Accordingly, the presentational devices can serve as strategies to call the audience's demand to reject the protagonist's standpoint and accept the antagonist's one. Imam Al-Hassan (PBUH) (as an antagonist) uses audience demand as a broad strategy through certain presentational devices. These certain sub-strategies that are highly recognized and respected by the addressees (Muaawiya and the Muslim people) are employed by the antagonist such as logos, intertextuality and other rhetorical strategies. Following the audience demand can lead to the refutation of all Muaawiya's allegations in terms of Imam Hassan's submission to him and stop all suspicions in the same regard.

Based on data analysis and finding discussions above, the study suggests that the model adopted above can be modified as illustrated in Figure 2 to be more suitable. 


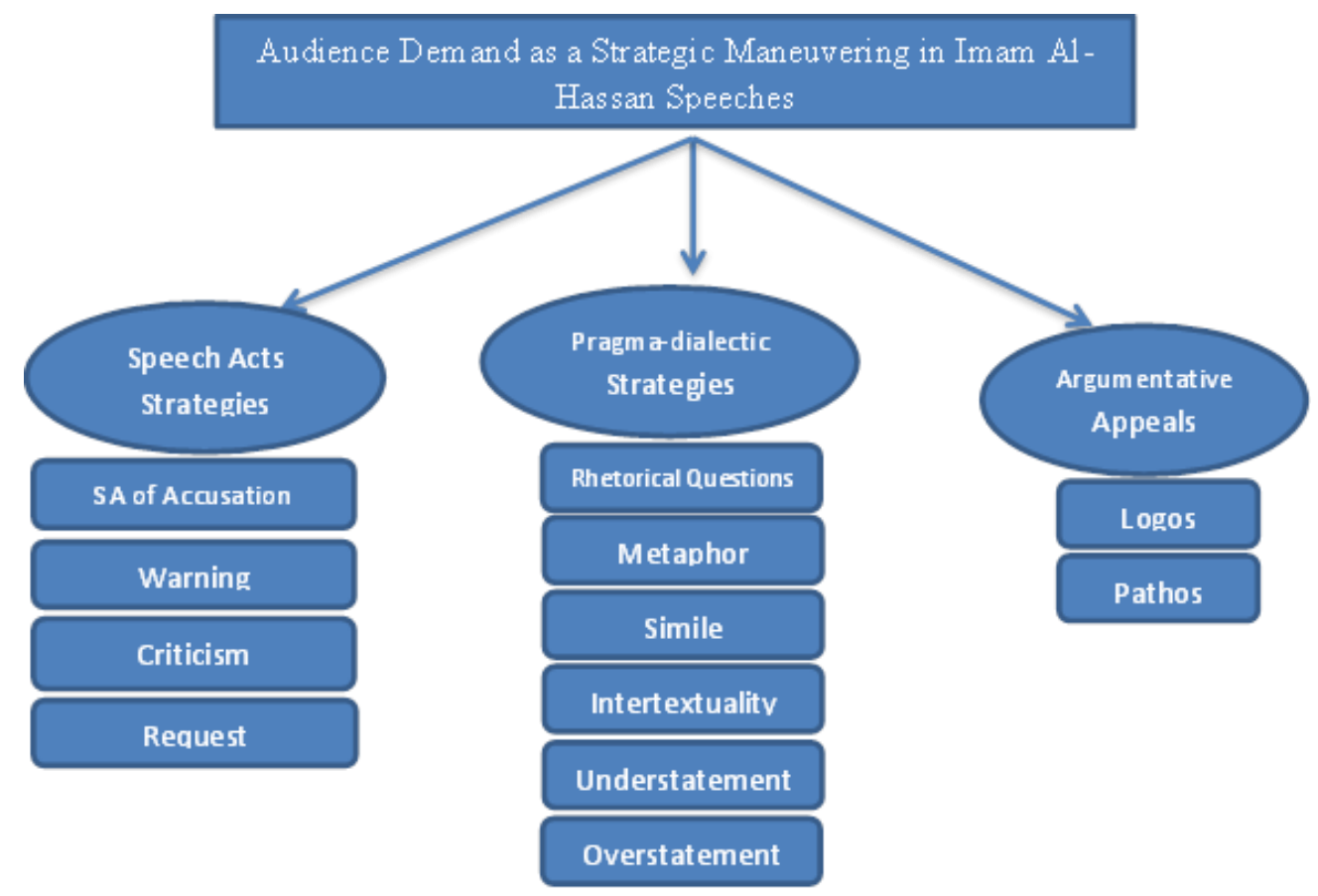

Figure 2, p. A Modified Version of Audience Demand as a Strategic Maneuvering in Imam Al-Hassan Speeches

\section{Conclusion}

The present study has come up with the following conclusions, p.

1. Strategic maneuverings are manifested through the audience demands in Imam Al-Hassan's (PBUH) speech. The strategies of audience demands are based on the presentational devices that are common to both the protagonist Muaawiya and antagonist (Imam Al-Hassan (PBUH)).

2. Imam Al-Hassan (PBUH) successfully refutes Muaawiya's standpoints and persuades the audience through the use of audience demands of the strategic manoeuvrings in that the addressees (Muaawiya and the audience) have no further standpoints to argue for.

3. Using such pragma-rhetorical and argumentative appeals strategies (logos and pathos) Imam Al-Hassan's (PBUH) recognized style refutes all Muaawiya's standpoints.

4. Imam Al-Hassan (PBUH) (antagonist) uses additional strategies such as intertextual devices, high-status power, and speech act of order to maneuver pragmatically and rhetorically. The strategies of audience demands positively affect Imam's Hassan arguments.

5. The model can receive some modifications to be more workable.

6. Imam Al-Hassan's Speeches are full of linguistic phenomena that can be furthered under different rhetorical pragmatics, pragmatics, and the like.

\section{References}

[1] Al-Ameen, M. (1976). A'yanul Shia, Darul Ta'aruf vl. 1.

[2] Andone, C. (2009). Accusing someone of an inconsistency as a confrontational way of strategic manoeuvring . In Eemeren, F. (ed.), Examining argumentation in context, p. Fifteen studies on 'strategic maneuvering. Amsterdam, p. Johns Benjamin, 153-170,

[3] Andone, C. (2012). The reasonableness of confrontational strategic maneuvering in political interviews". In Eemeren, F. and Garssen, B. (eds), Exploring Argumentative Contexts. Amsterdam, p. John Benjamins Publishing Company.

[4] Andone, C., and Gâţ̧ă, A. (2011). Maneuvering Strategically with Dissociation in a Political Inerview". In Feteris, E., Garssen, B. and Henkemans, F. (eds.), Keeping in Touch with Pragma-Dialectics. Amsterdam, p. John Benjamin, 5-21.

[5] Al-Qarashi, B. (2011). Hayatul Imam AL-Hassan (Imam Al-Hassan's Life). Darul Balaghah.

[6] Austin, J. (1962). How to Do Things with Words. Oxford, p. Clarendon Press. 
[7] Brown, P., \& Levinson, S. (1987). Universals in Language Use, p. Politeness Phenomena. Cambridge, p. Cambridge University Press.

[8] Colston, H., \& Gibbs, R. (2007). A Brief History of Irony". In Colston, H. and Gibbs, R. (eds.), Irony in Language and Thought, p. A Cognitive Science Reader. New Year, p. Taylor and Francis Group, LLC. 3-24, 2007.

[9] Cruse. A. (2006). A Glossary of Semantics and Pragmatics. Edinburgh, p. Edinburgh University Press. 2006

[10] Dews, S., \& Winner, E. (2011). Obligatory Processing of Literal and Nonliterak Meaing in Verbal Irony". Journal of Pragmatics, 43, 1579 - 1599, 2011.

[11] Eemeren, F. (2001). The State of the Art in Argumentation Theory". In F. van Eemeren (ed.) Crucial Concepts in Argumentation Theory. Amsterdam, p. Amsterdam University Press, pp. 11-26.

[12] Eemeren, F. (2010). Strategic Maneuvering in Argumentative Discourse. Amsterdam / Philadelphia, p. John Benjamins Publishing Company.

[13] Eemeren F. and Houtlosser, P. (2009). 'Strategic Maneuvering, p. Examining Argumentation in Context'. In Examining Argumentation in Context, p.Fifteen studies on strategic Maneuvering. Amsterdam / Philadelphia, p. John Benjamins Publishing Company, pp. 1-24

[14] Eemeren, F., \& Grootendorst, R. (1983). Speech Acts in Argumentative Discussions. Dordrecht, p. Foris Publications.

[15] Eemeren, F., \& Grootendorst, R. (1992). Argumentation, Communication, and Fallacies, p. A Pragma-Dialectical Perspective. New Jersey, p. Lawrence Erlbaum Associates, Inc.

[16] Eemeren, F., \& Grootendorst, R. (2006). Analyzing Argumentative Discourse". In R. Trapp and J. Schuetz (eds.) Perspectives on Argumentation, p. Essays in Honor of Wayne Brockriede. New York, p. International Debate Education Association, pp. 86106.

[17] Eemeren, F., \& Grootendorst, R. and Henkemans, A., Blair, J. Johnson, R. Krabbe, E. Plantin, D. Walton, C. Willard, C. Woods, J. and Zarefsky, D. (1996). Fundamentals of Argumentation Theory, p. A Handbook of Historical Backgrounds and Contemporary Developments. New Jersey, p. Lawrence Erlbaum Associates, Inc..

[18] Eemeren, F. Grootendorst, R., \& Henkemans, A. (2002). Argumentation, p. Analysis, Evaluation, Presentation. New Jersey, p. Lawrence Erblaum Associates, Inc.

[19] Gottweis, H. (2007). Rhetoric in policy making, p. Between pathos, ethos, and logos. In Fischer, F., Miller, G. and Sidney, M. (Eds.), Handbook of Public Policy Analysis. United States of America, p. Taylor and Francis group, LLC, $237-250$.

[20] Henckemans, A. (2009 ). Manoeuvring Strategically with Rhetorical Questions'. In F. Eemeren and B. Grassen (eds.) Pondering On Problems of Argumentation, p.Twenty Essays on Theoretical Issues. Springer Science+Business Media B.V, pp. 15-25.

[21] Houtlosser, P. (2001). Points of View. In F. van Eemeren (ed.) Crucial Concepts in Argumentation Theory. Amsterdam, p. Amsterdam. University Press, pp. 27-50.

[22] Kemp, P. (2001). Aristotle in the classroom, p. A rhetorical bridge between literature and composition". (Unpublished opinion paper). US Department of Education, p. ERIC.

[23] Larson, M. (1984). Meaning-Based Translation. London, Bradford.

[24] Lyons, J. (1977). Semantics. Cambridge, p. Cambridge University Press.

[25] Nguyen, M. (2005). Criticizing and responding to criticism in a foreign language, p. A study of Vietnamese learners of English". Unpublished doctoral thesis. Auckland, p. The University of Auckland.

[26] O'Keefe, D. (2009). Persuasive effects of strategic maneuvering, p. Some findings from meta-analyses of experimental persuasion effects research'. In F. Eemeren (ed.) Examining Argumentation in Context, p.Fifteen studies on strategic maneuvering. Amsterdam / Philadelphia, p. John Benjamins Publishing Company, 285-296

[27] Quirk, R. (2010). A comprehensive grammar of the English language. Pearson Education India.

[28] Roy, A. (1981). The Function of Irony in Discourse, Text 1(4), 407-423

[29] Taraman, J. (2010). You agree, don't you? 'Strategic Maneuvering' with Premise-eliciting-questions". [M.A Thesis]. Universiteit van Amsterdam.

[30] Tindale, C. (2009). Constrained maneuvering, p. Rhetoric as a rational enterprise. In F. Eemeren. (ed.) Examining Argumentation in Context, p. Fifteen Studies on Strategic Maneuvering. Amsterdam, p. John Benjamin Publishing Company, 41-61

[31] Tracy, K., Van Dusen, D. Robinson, S. (1987). Good and bad criticism, p. a descriptive analysis. Journal of Communication, 37, 46-59

[32] Zarfesky, D. (2006). Strategic Maneuvering through Persuasive Definitions, p. Implications for Dialectic and Rhetoric'. In Argumentation, 20, pp. 399-416. 